\title{
Article \\ Strategies to Reduce Crop Water Footprint in Intensive Wheat-Maize Rotations in North China Plain
}

\author{
Di Zhang 1,2,3,4,+, Dongxiao Li ${ }^{1,+}$, Haoran Li ${ }^{1}$, Hongguang Wang ${ }^{1}$, Jinna Liu ${ }^{2}$, Hui Ju ${ }^{4}$, William D. Batchelor ${ }^{3}$, \\ Ruiqi $\mathrm{Li}^{1}$ and Yanming $\mathrm{Li}^{1, *}$
}

1 State Key Laboratory of North China Crop Improvement and Regulation, Key Laboratory of Crop Growth Regulation of Hebei Province, College of Agronomy, Hebei Agricultural University, Baoding 071000, China; zhangdi0101@sina.com (D.Z.); lidongxiao.xiao@163.com (D.L.); lihaoran@hebau.edu.cn (H.L.); wanghongguang@hebau.edu.cn (H.W.); nxylrq@hebau.edu.cn (R.L.)

2 Department of Biological Engineering, Yangling Vocational \& Technical College, Xianyang 712000, China; sasaas_lt@163.com

3 Biosystems Engineering Department, Auburn University, Auburn, AL 36830, USA; wdb0007@auburn.edu

4 Institute of Environment and Sustainable Development in Agriculture, Chinese Academy of Agricultural Science, Beijing 100081, China; juhui@caas.cn

* Correspondence: nxzwst@hebau.edu.cn; Tel.: +86-150-7525-8795

+ These authors contributed equally to this work.

Citation: Zhang, D.; Li, D.; Li, H.; Wang, H.; Liu, J.; Ju, H.; Batchelor, W.D.; Li, R.; Li, Y. Strategies to Reduce Crop Water Footprint in Intensive Wheat-Maize Rotations in North China Plain. Agronomy 2022, 12, 357. https://doi.org/10.3390/ agronomy12020357

Academic Editor: Alejandro Galindo

Received: 2 January 2022

Accepted: 29 January 2022

Published: 31 January 2022

Publisher's Note: MDPI stays neutral with regard to jurisdictional claims in published maps and institutional affiliations.

Copyright: (C) 2022 by the authors. Licensee MDPI, Basel, Switzerland. This article is an open access article distributed under the terms and conditions of the Creative Commons Attribution (CC BY) license (https:// creativecommons.org/licenses/by/ $4.0 /)$

\begin{abstract}
The intensive use of groundwater and nitrogen fertilizer has led to serious negative impacts on the environment of the North China Plain (NCP). Water footprint is an emerging approach to assess the consumptive water use and the environmental impacts on winter wheat-summer maize systems. A seven-year rotation experiment was conducted to collect data on wheat and maize growth response to nitrogen rates and irrigation schedules and to explore how the water footprint was affected, using DSSAT 4.6 Wheat and Maize crop models. Results showed that the increase in farm inputs contributed greatly to the increase in water footprint, primarily through the grey water footprint. The water footprints of maize and wheat were more sensitive to the nitrogen rate and irrigation, respectively. An irrigation of $160 \mathrm{~mm}$ produced a minimum total water footprint and higher yield for wheat. The grey water footprint of maize increased linearly when the nitrogen rate applied to maize exceeded $60 \mathrm{~kg} \mathrm{ha}^{-1}$. Water-saving irrigation with $300 \mathrm{~kg} \mathrm{ha}^{-1}$ of nitrogen can maintain a higher grain yield and have little impact on the environment. The approach used and the results can help to develop management strategies to maintain high yields while minimizing the water footprint in NCP.
\end{abstract}

Keywords: water footprint; winter wheat; summer maize; rotation; DSSAT model

\section{Introduction}

The winter wheat-summer maize double cropping system in the North China Plain (NCP) is one of the most intensive agricultural systems worldwide and this rotation is widely used in Asian countries [1,2]. The North China Plain produces $56 \%$ of the wheat and $25 \%$ of the maize grain in China [3]. While the productivity of wheat and maize has been increasing in the recent decades, the intensive use of groundwater and nitrogen fertilizer has led to serious negative impacts on the environment. Therefore, the sustainability of intensive double cropping systems has been increasingly questioned [4,5]. To further promote water conservation in crop production, it is urgent to explore a greater adoption of water-efficient production systems [6,7].

Water footprint analysis can provide information on complex water relationships for policy makers, business leaders, regulators, and managers, to make decisions for this increasingly scarce resource [8,9]. The water footprint is defined as the volume of freshwater used to produce a crop measured over the various steps of the production chain [10]. The water footprint has three components: consumption of surface and ground water (blue 
water), consumption of rainwater in crop production (green water), and the volume of freshwater that is required to assimilate the load of pollutants during the crop production process (grey water) [10].

Many water footprint studies have been carried out to focus on water-intensive industrial processes and crops, such as cotton [11], tomato [12], strawberry [13], sugarcane [14], maize [15], olive [16], winter wheat [17], and others [18]. Gleeson et al. [19] compared the rate of global groundwater depletion with the rate of natural renewal and the supply needed to support ecosystems, and they found that the net global water footprint was driven by a few heavily overexploited aquifers. The global water footprint consumed by humans has been quantified by Hoekstra and Mekonnen [20]. They reported that the consumption of cereal products made the largest contribution to the water footprint of the average consumer. Grey water footprint was mainly generated from the production of domestic final demand [21]. Mekonnen and Hoekstra [22] reported that if the water footprint was reduced by $10 \%$ for current global crop production, the global water saving in crop production would be $52 \%$ compared to the reference water consumption. Therefore, developing management practices to reduce the water footprint in agricultural production would be a great benefit to society.

Morillo et al. [13] suggested that joint evaluation of crop water footprint and irrigation management will become a powerful tool for assessing irrigation processes. They used the methodology to evaluate strawberry production, and found that the blue water footprint was 55-66\% higher than the water allowance proposed under lower water regulations. Chukalla et al. [23] comprehensively analyzed the potential to reduce the consumptive water footprint of a few crops at the field level by changing management practice such as irrigation technique, irrigation strategy and mulching practice, and they found that the highest reduction in consumptive water footprint was $28 \%$ for drip irrigation. Unreasonable nutrient management mainly contributed to pollution of freshwater. Many previous studies have assumed that $10 \%$ of the nitrogen application rate was subject to leaching and runoff. Brueck and Lammel [24] considered that this value was underestimated if the rates exceeded economic nitrogen rates. Nitrogen application rates should vary according to irrigation levels. It should be reduced under water limited condition for more efficient use of water and nitrogen [25]. However, there are still few studies on the effect of nitrogen rates and irrigation amount on water footprint. Although research on water footprint has been increasing rapidly, further studies focusing on how combinations of specific techniques and practices can actually lead to water footprint reduction are necessary [17].

Most former studies used the CROPWAT [13,17,26,27], input-output method [28,29] or AQUACROP $[17,23]$ to quantify the water footprint of a crop. These models or methods used to estimate the yield depend on a simplified linear model which accounts for the effect of water deficit on yield reduction only, leaving out other factors, such as fertilizer application rate, soil salinity and crop growing characteristics [27]. A better estimate of crop water footprint could be made using process-oriented models that account for other yield-limiting factors. The Decision Support System for Agrotechnology Transfer (DSSAT) model is a widely used cropping system simulation model. Several researchers showed that once the model was properly calibrated, it was able to simulate the biomass growth, grain yield, and water and nitrogen balance in response to agricultural management $[4,30,31]$. DSSAT has already been successfully used all over the world for different purposes, such as climate change response [32,33], irrigation strategies [34,35], nitrogen management [36], plant density $[37,38]$, rotation $[39,40]$, etc. The DSSAT model can simulate the dynamic changes in soil water, evapotranspiration, $\mathrm{N}$ leaching and the potential yield of crops on a daily basis. Therefore, it could be a good tool to evaluate the water footprint. The DSSAT-wheat model has been used more and more to simulate water footprint of crops in many countries [41,42]. However, none of the previous studies focused on the effect of agricultural management, such as nitrogen rate and irrigation scheduling, on the water footprint of crops estimated by the DSSAT model. 
In this paper, a systematic study including single- and multi-factor simulation was conducted to investigate wheat and maize production and water footprint analysis using the DSSAT-Wheat and -Maize model. The objectives of this study were (1) to evaluate the ability of Decision Support System for Agrotechnology Transfer (DSSAT v4.6, DSSAT Foundation Team, Florida, USA) to simulate continuous crop yields for winter wheatsummer maize rotation; (2) to understand the response of wheat and maize water footprint to irrigation scheduling and nitrogen rate; (3) to determine best management strategies in the North China Plain to optimize yield and water footprint. This detailed knowledge of water footprint of the intensive agricultural system may provide options for more management strategies in other intensive management cropping systems around the world.

\section{Materials and Methods}

\subsection{Study Site}

A long-term fertilizer experiment was conducted at Gaocheng District, Shijiazhuang City, Hebei Province, which is in the central NCP. The typical cropping system is a winter wheat and summer maize double cropping system. Historical weather data were measured from 1966 to 2015. The region is semi-arid with a monsoon climate, and historical minimum and maximum daily temperatures ranged from $-7.4-2.8{ }^{\circ} \mathrm{C}$ in winter to $22.4-32.0^{\circ} \mathrm{C}$ in summer (Figure 1). Annual average precipitation is $485.9 \mathrm{~mm}$, with more than $70 \%$ occurring from June to September. Only 20-30\% of the precipitation typically occurs from October to early June during the wheat growing season. The soil type was clay-loam.

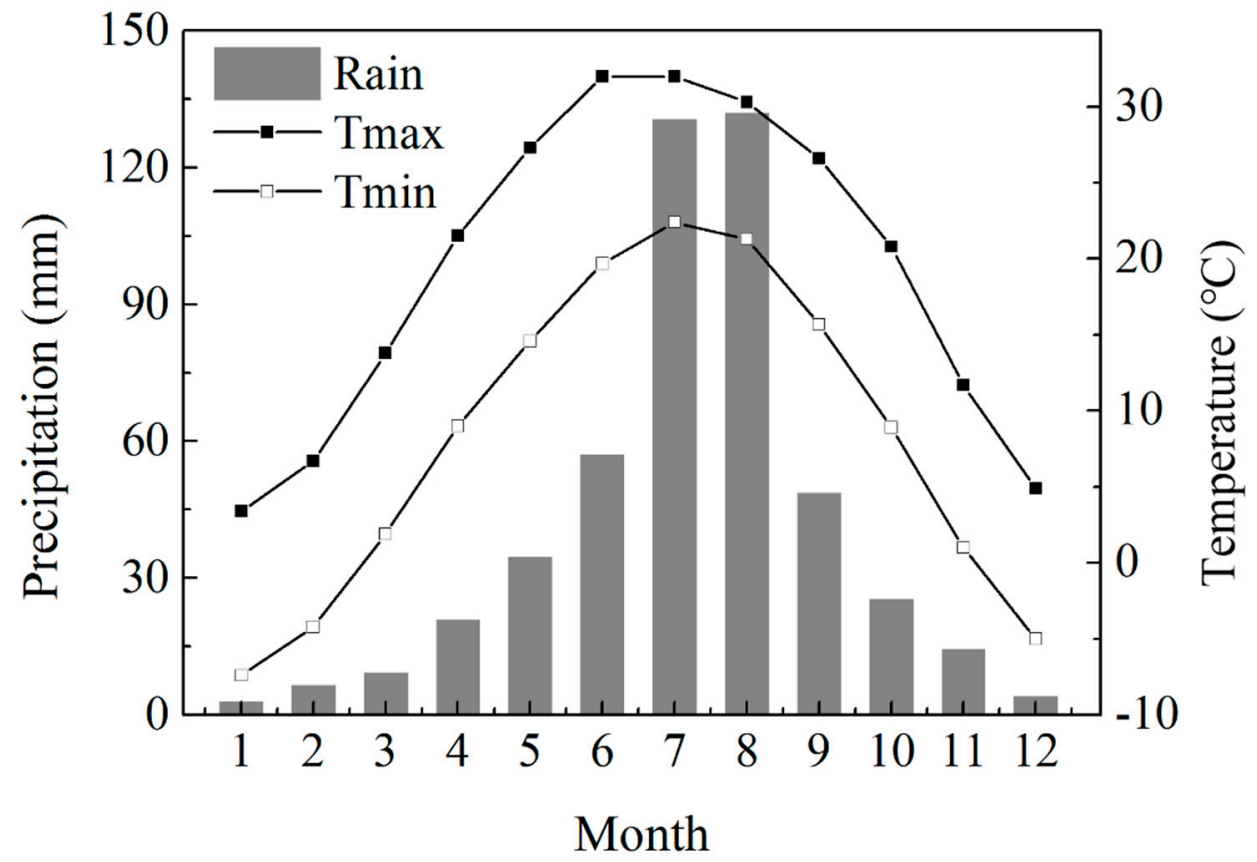

Figure 1. Distribution of the monthly rain, maximum $\left(\mathrm{T}_{\max }\right)$ and minimum temperature $\left(\mathrm{T}_{\min }\right)$ at Gaocheng, China, over 49 years.

\subsection{Field Management and Experiment Data}

The experiment was set up as a split-plot design with two irrigation treatments in the main plots and three nitrogen rates in the sub-plots described by Lv et al. [43] and Zhang et al. [44]. Each plot is $4.8 \mathrm{~m} \times 5.4 \mathrm{~m}$. The two irrigation levels in the main plots were limited irrigation and full irrigation with border irrigation method. The limited irrigation treatment consisted of a single irrigation at jointing for wheat and a single irrigation at sowing for maize. The full irrigation included two irrigations at jointing and anthesis for wheat and two irrigations at sowing and 12-leaf stage for maize. An extra irrigation was applied to summer maize in 2008 and 2009. The three nitrogen levels of the subplots 
were 180, 240, $300 \mathrm{~kg} \mathrm{~N} \mathrm{ha}^{-1}$ for each crop. The experiment began in the fall of 2006 and continued through 2013 . For winter wheat, $50 \%$ of the $\mathrm{N}$ fertilizer was applied at sowing as basal fertilizer, and 50\% was applied as topdressing by broadcasting onto the soil surface before irrigation at the jointing stage. For summer maize, $40 \%$ of the $\mathrm{N}$ fertilizer was applied at sowing, while $60 \%$ of fertilizer was applied at the 12 -leaf stage. The amount of each irrigation event was approximately 70-80 $\mathrm{mm}$. The local cultivar of winter wheat and maize was planted each season. Winter wheat was sown in mid-October and harvested in early June, followed immediately by the sowing of maize in mid-June and harvesting in early October. Weeds, insect pests, and diseases were properly controlled and the crops were not limited by other nutrients.

\subsection{Model Calibration and Evaluation}

The DSSAT version 4.6 CSM-CERES-Wheat and CERES-Maize models [30,45] were used to simulate above-ground biomass, grain yield, and canopy nitrogen accumulation at maturity for the field experiments. The model requires daily weather data, soil profile characteristics, crop management data, and genotype coefficients as general inputs. Daily weather data from 1966 to 2015 including daily average, maximum and minimum temperature, precipitation, and sunshine hours were obtained from the weather station located in Gaocheng, China. Daily solar radiation was calculated using daily sunshine hours provided with Weatherman software, DSSAT 4.6 (DSSAT Foundation Team, Gainesville, FL, USA). The data of Yang et al. [46] were used to establish soil profile characteristics including lower limit, drained upper limit and saturated water holding capacity for different soil depths. The cultivar coefficients required to run the DSSAT-Wheat and Maize models are shown in Tables 1 and 2. A standard iterative calibration procedure was used to estimate the genetic coefficients that minimized error in grain yield at maturity. Genetic coefficients were calibrated using full irrigation treatments. Following calibration, the model was evaluated using the limited irrigation treatments.

Table 1. Genetic coefficients calibrated for winter wheat cultivar.

\begin{tabular}{ccc}
\hline Cultivar Coefficient & Definition & Calibrated Value \\
\hline P1V & Days, optimum vernalizing temperature, required for vernalization & 45 \\
P1D & Photoperiod response (\% reduction in rate $10 \mathrm{~h}^{-1}$ drop in photoperiod) & 70 \\
P5 & Grain filling (excluding lag) phase duration ( ${ }^{\circ}$ C day) & 720 \\
G1 & Kernel number per unit canopy weight at anthesis (g) & 30 \\
G2 & Standard kernel size under optimum conditions (mg) & 29 \\
G3 & Standard, non-stressed mature tiller wt (including grain, g dry weight) & 1.0 \\
PHINT & Interval between successive leaf tip appearances ( ${ }^{\circ}$ C day) & 90 \\
\hline
\end{tabular}

Table 2. Genetic coefficients calibrated for summer maize cultivar.

\begin{tabular}{crc}
\hline Cultivar Coefficient & Definition & Calibrated Value \\
\hline P1 & Degree days (base $8{ }^{\circ} \mathrm{C}$ ) from emergence to end of juvenile phase & 260.0 \\
P2 & Photoperiod sensitivity coefficient $(0-1.0)$ & 0.3 \\
P5 & Thermal time from silking to physiological maturity & 870.0 \\
G2 & Maximum potential number of kernels per plant & 820.0 \\
G3 & Kernel filling rate during the linear grain filling stage and under & 9.0 \\
PHINT & optimum conditions (mg day ${ }^{-1}$ ) & 38.9 \\
\hline
\end{tabular}

\subsection{Systematic Exploration of Management Options of Irrigation and Nitrogen}

After calibration and evaluation of the genetic coefficients, the DSSAT-CERES-Wheat and -Maize models were used to explore systematically and comprehensively how different management practices affect long-term yield and water footprint. The goal was to determine the best management practices that give a lower water footprint while maintaining 
an acceptable long-term yield. A weather dataset from Gaocheng, China, including daily minimum and maximum air temperatures, daily precipitation, and solar radiation from 1966 to 2015 was available for this analysis. The wheat cultivar and maize cultivar used for calibration and evaluation were used in the long-term simulations. The use of the fixed cultivars eliminates the impacts of other factors, and enables the investigation of the impact of climate variability and nitrogen as well as water supply levels on crop growth [47]. Table 3 shows the management scenarios that were simulated from 1966-2015.

Table 3. Irrigation and nitrogen rate simulated with the CERES-Wheat and -Maize model.

\begin{tabular}{ccccc}
\hline \multirow{2}{*}{ Scenario } & \multicolumn{2}{c}{ Wheat } & Maize \\
\cline { 2 - 5 } & $\begin{array}{c}\text { Irrigation } \\
(\mathbf{m m})\end{array}$ & $\begin{array}{c}\text { Nitrogen } \\
\mathbf{( k g ~ h a}^{-\mathbf{1}} \mathbf{)}\end{array}$ & $\begin{array}{c}\text { Irrigation } \\
(\mathbf{m m})\end{array}$ & $\begin{array}{c}\text { Nitrogen } \\
(\mathbf{k g ~ h a}\end{array}$ \\
\hline 1 & $0,80,160,240,320$ & 240 & 160 & 240 \\
2 & 160 & $0,60,120,180,240,300$ & 160 & 240 \\
3 & 160 & 240 & $0,80,160,240,320$ & 240 \\
4 & 160 & 240 & 160 & $0,60,120,180,240,300$ \\
\hline
\end{tabular}

In scenario 1 , the five irrigation treatments were zero, one ( $80 \mathrm{~mm}$ at sowing), two ( $80 \mathrm{~mm}$ at sowing and $80 \mathrm{~mm}$ at jointing), three $(80 \mathrm{~mm}$ at sowing, $80 \mathrm{~mm}$ at jointing and $80 \mathrm{~mm}$ at anthesis) and four (80 mm at sowing, $80 \mathrm{~mm}$ at jointing, $80 \mathrm{~mm}$ at anthesis and $80 \mathrm{~mm}$ at grain filling) times irrigations for winter wheat. The rotated maize was simulated with two irrigations ( $80 \mathrm{~mm}$ at sowing and $80 \mathrm{~mm}$ at 12-leaf expansion). In scenario 3, there were zero, one ( $80 \mathrm{~mm}$ at sowing), two ( $80 \mathrm{~mm}$ at sowing and $80 \mathrm{~mm}$ at 12-leaf expansion), three $(80 \mathrm{~mm}$ at sowing, $80 \mathrm{~mm}$ at 12-leaf expansion and $80 \mathrm{~mm}$ at tasseling) and four ( $80 \mathrm{~mm}$ at sowing, $80 \mathrm{~mm}$ at 12-leaf expansion, $80 \mathrm{~mm}$ at tasseling and $80 \mathrm{~mm}$ at grain filling) times irrigation treatments for maize. In the rotation, the wheat was simulated with two irrigations ( $80 \mathrm{~mm}$ at jointing and $80 \mathrm{~mm}$ at anthesis). In scenarios 2 and 4 , the crop was simulated with two irrigations at jointing and anthesis for wheat, and at sowing and 12-leaf expansion for maize. In all scenarios, $50 \%$ of $\mathrm{N}$ fertilizer was applied at sowing as basal fertilizer for both wheat and maize, and $50 \%$ of was applied at jointing for wheat, and at 12-leaf expansion for maize.

\subsection{Water Footprint Calculation Methods}

The water footprint (WF) of crop production was defined as the sum of green water footprint $\left(W F_{\text {green }}\right)$, blue water footprint $\left(W F_{\text {blue }}\right)$ and grey water footprint $\left(W F_{\text {grey }}\right)$ of the wheat-maize cropping system. Green water footprint refers to consumption of water stored in the root zone as a result of precipitation. $W F_{\text {green }}$ was computed by comparing evapotranspiration $(E T)$ simulated by the model against the cumulative precipitation $(P)$ during the growing season [15]. Blue water footprint was defined as the consumption of surface and groundwater from irrigation. In this study, it refers to loss of available water extracted from groundwater. The $W F_{\text {green }}$ and $W F_{\text {blue }}$ were calculated as:

$$
\begin{gathered}
W F=W F_{\text {green }}+W F_{\text {blue }}+W F_{\text {grey }} \\
W F_{\text {green }}=\frac{W_{\text {green }}}{Y} \\
W F_{\text {blue }}=\frac{W_{\text {blue }}}{Y} \\
W_{\text {green }}=10 \times \min (E T, P) \\
W_{\text {blue }}=10 \times \text { irrigation }
\end{gathered}
$$


where WF is the total WF of crop production, with a unit of $\mathrm{m}^{3} \mathrm{t}^{-1} ; W F_{\text {green }}$ is the green WF; $W F_{\text {blue }}$ is the blue $W F ; W_{\text {blue }}$ is the blue water evapotranspiration $(\mathrm{mm}) ; E T$ is the water evapotranspiration (mm); $P$ is the precipitation $(\mathrm{mm}), Y$ is the crop yield $\left(\mathrm{t} \mathrm{ha}^{-1}\right)$.

Grey water footprint refers to the freshwater required to assimilate the load of pollutants, and it expresses the degradative water use. In this study, $N_{\text {leaching }}$ was computed by the crop models and the grey water footprint was computed as the water required to assimilate $\mathrm{N}$ lost below the root zone for each crop and season. The permissible concentration of $\mathrm{N}$ in drinking water is $10 \mathrm{mg} \mathrm{L}^{-1}$. The $W F_{\text {grey }}$ was defined as the ratio of degradative water use over the crop yield:

$$
\begin{gathered}
W F_{\text {grey }}=\frac{W_{\text {grey }}}{Y} \\
W_{\text {grey }}=\frac{N_{\text {leaching }}}{\rho_{0}-\rho_{\text {nat }}}
\end{gathered}
$$

where $W F_{\text {grey }}\left(\mathrm{m}^{3} \mathrm{ha}^{-1}\right)$ is the grey $W F ; W_{\text {grey }}\left(\mathrm{m}^{3} \mathrm{ha}^{-1}\right)$ is the degradative water use; $N_{\text {leaching }}\left(\mathrm{kg} \mathrm{ha}^{-1}\right)$ is the amount of $\mathrm{N}$ leaching; $\rho_{0}$ is the maximum acceptable concentration $\left(10 \mathrm{mg} \mathrm{L}^{-1}\right) ; \rho_{\text {nat }}$ is the concentration in natural water, assumed to be $0 \mathrm{mg} \mathrm{L}^{-1}$.

\subsection{Statistical Analysis}

To quantify the goodness of fit of the model, four common statistical indicators were used: root mean square errors (RMSE), normalized root mean square errors (nRMSE), mean error $(M E)$, and index of agreement ( $d$ value) $[48,49]$.

$$
\begin{gathered}
R M S E=\sqrt{\frac{\sum_{i=1}^{n}\left(S_{i}-M_{i}\right)^{2}}{n}} \\
n R M S E=\frac{R M S E}{M_{\mathrm{avg}}} \\
M E=\frac{1}{n} \sum_{i=1}^{n}\left(S_{i}-M_{i}\right) \\
d=1-\frac{\sum_{i=1}^{n} S_{i}-M_{i}}{\sum_{i=1}^{n}\left(\left|S_{i}-M_{\mathrm{avg}}\right|+\left|M_{i}-M_{\mathrm{avg}}\right|\right)}
\end{gathered}
$$

where $n$ is the total number of data points, $S$ and $M$ represent the simulated and measured values, and $M_{\text {avg }}$ is the average of measured values.

It is generally agreed that the model performance is excellent when its value of nRMSE is less than $10 \%$, good when it is between $10-20 \%$, fair when between $20-30 \%$, and poor when greater than $30 \%$ [50].

Correlation analysis was used to relate the parameters among grain yield, $\mathrm{N}$ leaching, ET, annual water footprint, and agricultural inputs to assess the possible factors affecting crop productivity and water footprint. The 'agricolae' package [51] was used to perform this analysis using R version 3.3.2 (R Foundation for Statistical Computing, Vienna, Austria). We used the structural equation model (SEM) to explore the pathways of how nitrogen and irrigation affected annual water footprint using R package 'lavaan' [52].

\section{Results}

\subsection{Model Calibration and Evaluation}

The winter wheat and summer maize experiments under full irrigation over 7 years were chosen to calibrate the genetic coefficients in the crop models. The genetic coefficients for wheat and maize after calibration are shown in Tables 1 and 2, respectively. Table 4 shows the resulting simulated and observed yields after calibration. Simulated yield of winter wheat agreed well with observations with a normalized $\mathrm{nRSME}<10 \%$ and a d-index greater than 0.84 across different nitrogen treatments under full irrigation. Although the 
simulated yield of summer maize was a little lower than observations, the performance of the calibrated DSSAT-Maize model was considered as acceptable with a normalized nRSME $<10 \%$ and a d-index close to 1 across different nitrogen treatments under full irrigation. These results indicated that the model was able to accurately simulate the production of winter wheat and summer maize rotation response to different nitrogen treatments in North China Plain.

Table 4. Comparison of observed and simulated grain yields for winter wheat and summer maize from 2006 to 2013.

\begin{tabular}{|c|c|c|c|c|c|c|c|c|c|c|c|c|}
\hline \multirow[b]{2}{*}{ Treatment } & \multicolumn{7}{|c|}{ Winter Wheat } & \multicolumn{5}{|c|}{ Summer Maize } \\
\hline & $n$ & $\begin{array}{c}\text { Observed } \\
\text { tha- } \mathrm{ha}^{-1}\end{array}$ & $\begin{array}{l}\text { Simulated } \\
\mathrm{tha}^{-1}\end{array}$ & $\begin{array}{c}\text { ME } \\
\mathrm{tha}^{-1}\end{array}$ & $\underset{\%}{\text { nRMSE }}$ & $d$ & $n$ & $\begin{array}{c}\text { Observed } \\
\text { tha } \text { ha }^{-1}\end{array}$ & $\begin{array}{l}\text { Simulated } \\
\text { tha }\end{array}$ & $\begin{array}{c}\mathrm{ME} \\
\mathrm{tha^{-1 }}\end{array}$ & $\underset{\%}{\text { nRMSE }}$ & $d$ \\
\hline \multicolumn{13}{|c|}{ Limited Irrigation } \\
\hline N180 & 7 & 6.995 & 6.284 & -0.711 & 12.55 & $0.86^{\circ}$ & 7 & 9.088 & 8.957 & -0.131 & 11.09 & 0.71 \\
\hline N240 & 7 & 6.919 & 7.433 & 0.514 & 12.90 & 0.70 & 7 & 8.947 & 9.083 & 0.136 & 9.56 & 0.83 \\
\hline N300 & 7 & 6.926 & 7.305 & 0.379 & 12.19 & 0.73 & 7 & 8.748 & 9.097 & 0.350 & 8.49 & 0.84 \\
\hline Total & 21 & 6.947 & 7.007 & 0.060 & 12.55 & 0.99 & 21 & 8.928 & 9.046 & 0.118 & 9.80 & 1.00 \\
\hline \multicolumn{13}{|c|}{ Full Irrigation } \\
\hline N180 & 7 & 8.069 & 8.004 & -0.065 & 5.84 & 0.93 & 7 & 9.475 & 8.610 & -0.865 & 9.82 & 0.73 \\
\hline N240 & 7 & 7.904 & 8.101 & 0.196 & 8.70 & 0.85 & 7 & 9.341 & 9.108 & -0.233 & 6.14 & 0.82 \\
\hline N300 & 7 & 8.074 & 8.101 & 0.027 & 8.27 & 0.84 & 7 & 9.146 & 9.107 & -0.039 & 9.54 & 0.72 \\
\hline Total & 21 & 8.016 & 8.068 & 0.053 & 7.69 & 0.87 & 21 & 9.321 & 8.942 & -0.379 & 8.66 & 1.00 \\
\hline
\end{tabular}

$\mathrm{N} 180,180 \mathrm{~kg} \mathrm{~N} \mathrm{ha}^{-1} ; \mathrm{N} 240,240 \mathrm{~kg} \mathrm{~N}^{-1} ; \mathrm{N} 300,300 \mathrm{~kg} \mathrm{~N}^{-1}$.

The observed data with different nitrogen treatments under limited irrigation over 7 years were used to evaluate the model for the study area (Table 4). The d-index for simulated and observed winter wheat grain yields ranged from 0.70 to 0.86 , for the three nitrogen treatments, and the nRSME was approximately $12 \%$. The d-index and nRSME of summer maize ranged from 0.71 to 0.84 , and from $8.49 \%$ to $11.09 \%$, respectively. The DSSAT-Wheat and -Maize simulated the grain yield of winter wheat and summer maize rotation for the evaluation dataset with reasonable accuracy.

The overall results indicate that the model simulated wheat and maize yield response to $\mathrm{N}$ and irrigation strategies very well. The nRMSE and d-index were $12.55 \%$ and 0.99 $(n=21)$ for winter wheat, and $9.80 \%$ and $1.00(n=21)$ for summer maize under limited irrigation. The values of nRMSE and d-index under full irrigation were $7.69 \%$ and 0.87 for winter wheat, and $8.66 \%$ and 1.00 for summer maize. The models gave good results in simulating the growth of winter wheat and summer maize with different nitrogen fertilizations under limiting irrigation condition compared to field data collected from 2006-2013. However, there was a slight underestimation of summer maize yield under full irrigation (Table 4). Though some deviations were found between simulated and observed yield under the full irrigation condition, the statistical analysis of the performance indicators showed that the deviations were acceptable. It can thus be used to investigate the effects of irrigation and nitrogen fertilizer on productivity and water balance of winter wheat and summer maize rotation at the study site.

\subsection{The Effect of Management on Water Footprint}

3.2.1. The Impact of Winter Wheat $\mathrm{N}$ and Irrigation Management on the Water Footprint of Winter Wheat

The water footprint was computed for different $\mathrm{N}$ strategies for winter wheat resulting from model runs using weather data from 1966-2015 and the calibrated cultivar coefficients. For these runs, irrigation was $160 \mathrm{~mm}$ at jointing and anthesis. Figure 2 shows the response of the long term average wheat water footprint to nitrogen rate and irrigation, respectively. The green and blue water footprint of winter wheat declined with increasing nitrogen rate, resulting in a decrease in the total water footprint for $\mathrm{N}$ rates less than $180 \mathrm{~kg} \mathrm{~N} \mathrm{ha}^{-1}$. As $\mathrm{N}$ rates increased above $180 \mathrm{~kg} \mathrm{ha}^{-1}$, the grey water footprint tended to increase, thus increasing the total water footprint of wheat. 

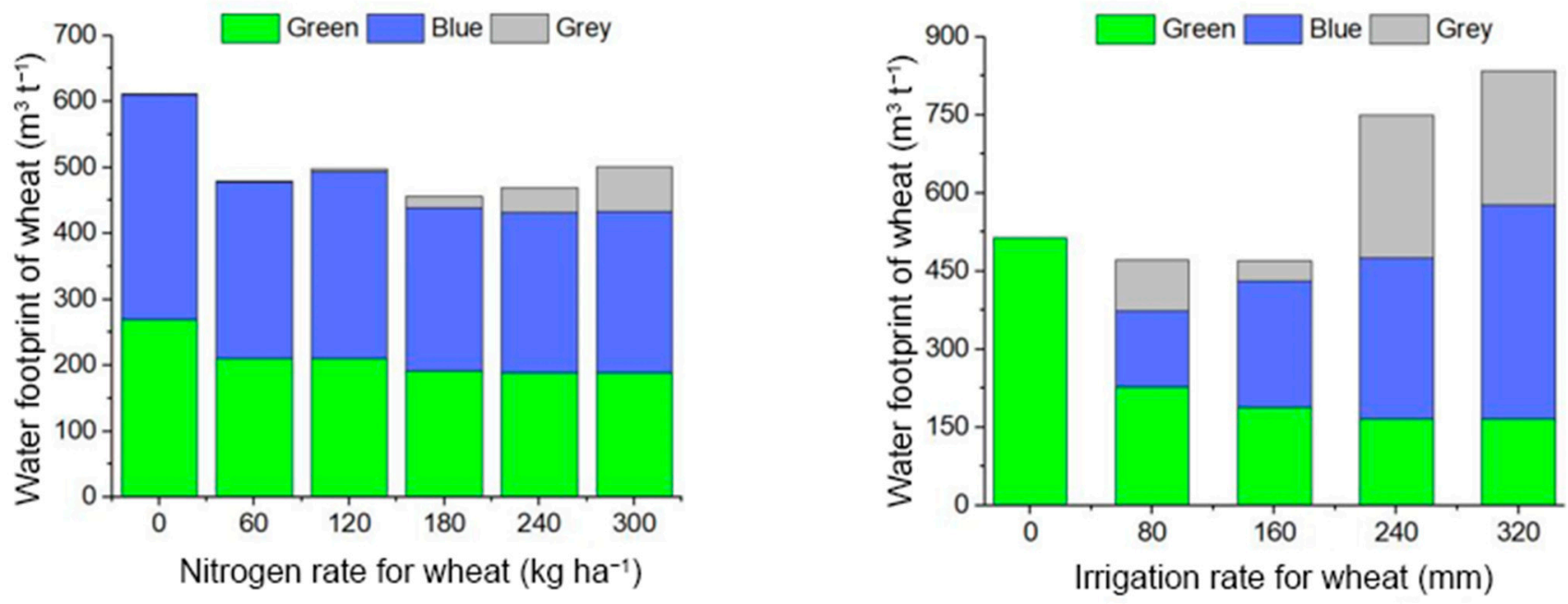

Figure 2. Water footprint of winter wheat: response to different management practices applied to winter wheat from 1966 to 2015.

A second analysis was run for wheat using $240 \mathrm{~kg} \mathrm{~N} \mathrm{ha}^{-1}$ and different irrigation amounts. The results showed that the response of the blue and green water footprint to irrigation rates were different. With increasing irrigation amounts, the blue water footprint of winter wheat increased, while the green water footprint decreased. When the irrigation amount was more than $160 \mathrm{~mm}$, the green water footprint was less than the blue water footprint. The grey water footprint increased irregularly with irrigation. The minimum total water footprint was achieved with $160 \mathrm{~mm}$ of irrigation. When irrigation was more than $160 \mathrm{~mm}$, the total water footprint increased due to the increase of blue and grey water footprint.

3.2.2. The Impact of Winter Wheat Irrigation and N Management on the Water Footprint of Summer Maize

The water footprint of summer maize was also affected by nitrogen rate applied to winter wheat (Figure 3). When summer maize was planted in rotation using a nitrogen rate of $240 \mathrm{~kg} \mathrm{ha}^{-1}$, the green and blue water footprint declined with increasing nitrogen rate applied to winter wheat. When the $\mathrm{N}$ rate applied to winter wheat was more than $120 \mathrm{~kg} \mathrm{ha}^{-1}$, the grey water footprint of summer maize increased, and thus the total water footprint increased dramatically. This suggested that excessive application of nitrogen fertilizer to winter wheat resulted in more nitrogen leaching to groundwater in the summer maize season.

The response of the water footprint of summer maize to different irrigation amounts applied to winter wheat is also shown in Figure 3. The green and blue water footprint for summer maize was not affected by irrigation applied to winter wheat. However, the grey water footprint of summer maize increased irregularly with winter wheat irrigation amounts. The total water footprint showed a similar tendency to the grey water footprint.

3.2.3. The Impact of Summer Maize Irrigation and N Management on the Water Footprint of Summer Maize

Water footprint components were simulated for summer maize using different $\mathrm{N}$ and irrigation levels for each of the 48 growth seasons (1967-2015) to assess the impact of nitrogen and irrigation (Figure 4) on the water footprint of summer maize. The green and blue water footprint declined with an increase in nitrogen rate; however, the grey water footprint, and thus the total water footprint, increased substantially with $\mathrm{N}$ levels above $60 \mathrm{~kg} \mathrm{ha}^{-1}$. 

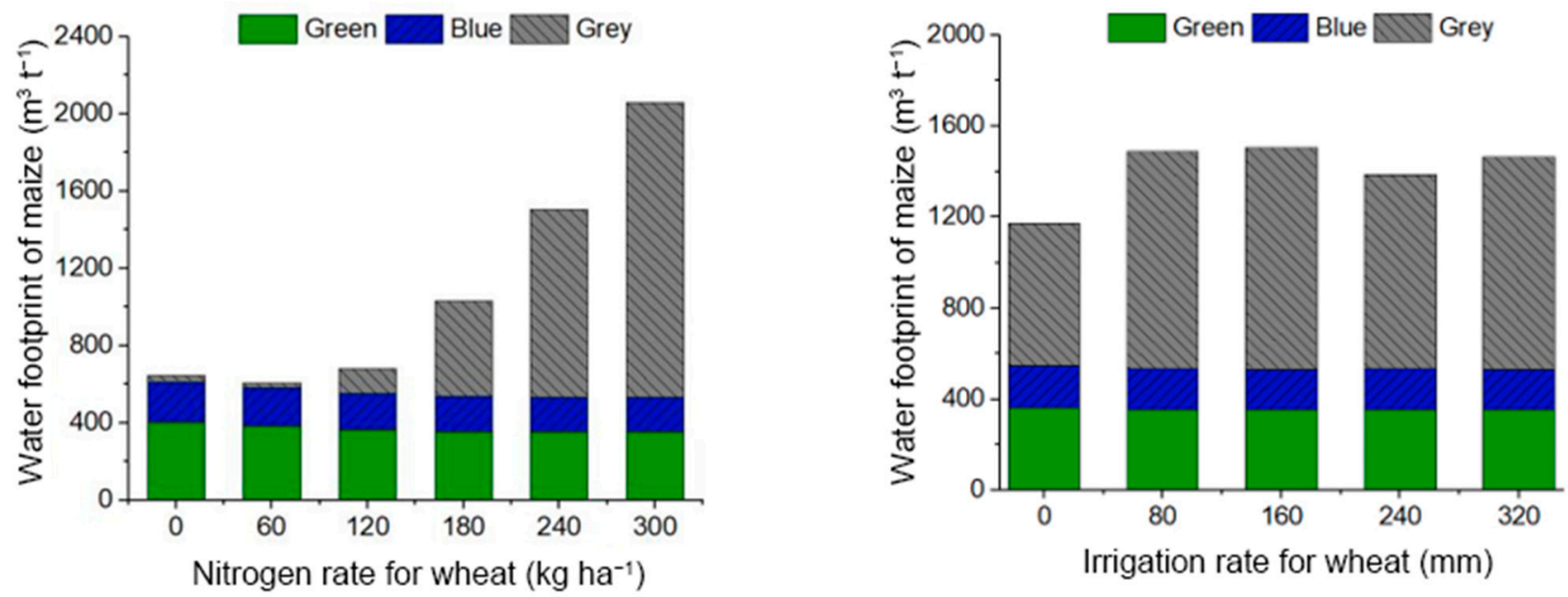

Figure 3. Water footprint of summer maize: response to nitrogen rate and irrigation applied to winter wheat from 1966 to 2015 . Summer maize was planted with $240 \mathrm{~kg} \mathrm{ha}^{-1}$ of nitrogen rate and $160 \mathrm{~mm}$ of irrigation.
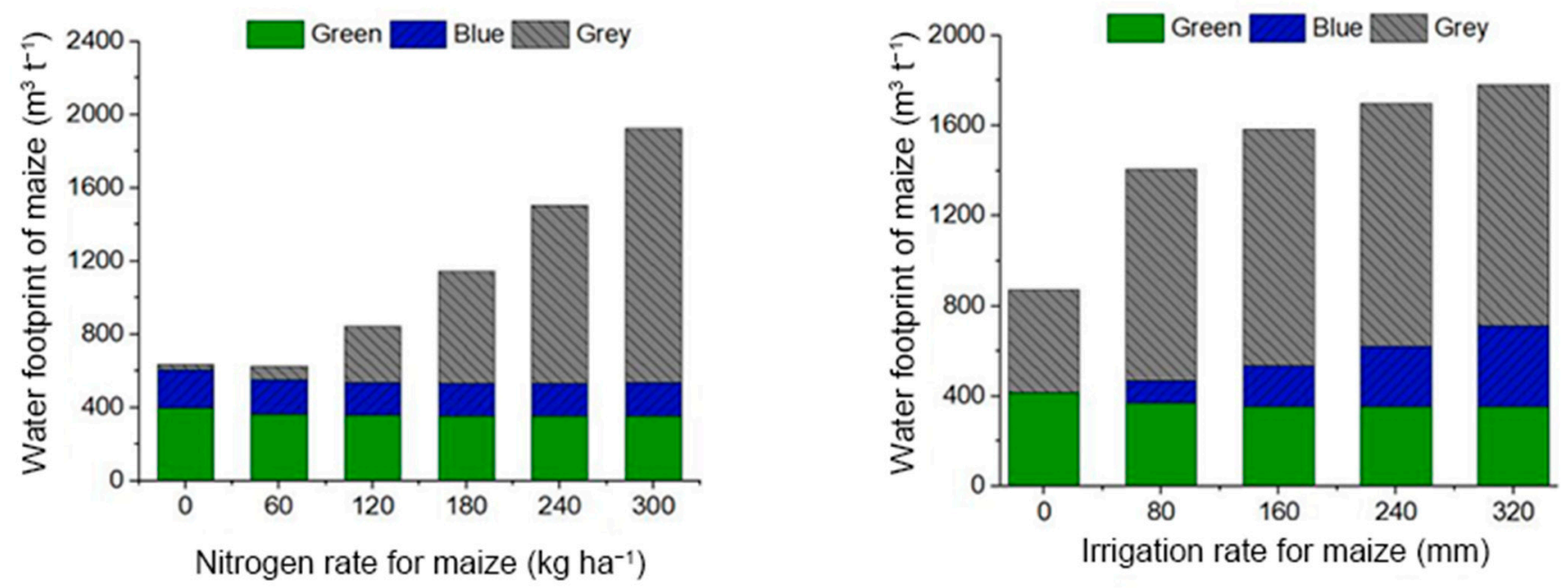

Figure 4. Water footprint of summer maize: response to different management practices applied to summer maize from 1967 to 2015.

The water footprint of summer maize generally increased with increasing irrigation applied to summer maize with an $\mathrm{N}$ application of $240 \mathrm{~kg} \mathrm{~N} \mathrm{ha}^{-1}$. There was a linear increase in blue water footprint of summer maize with increased irrigation rate in summer maize. The grey water footprint increased from 455 to $1049 \mathrm{~m}^{3} \mathrm{t}^{-1}$ when the amount of irrigation increased from 0 to $160 \mathrm{~mm}$. When the amount of irrigation exceeded $160 \mathrm{~mm}$, the grey water footprint remained stable.

3.2.4. The Impact of Summer Maize Irrigation and N Levels on the Water Footprint of Winter Wheat

The water footprint was dominated by many factors, including grain yield, and green, blue as well as grey water. Figure 5 shows the response of the winter wheat water footprint to different nitrogen and irrigation levels applied to summer maize. Compared with the treatment with no nitrogen fertilizer in summer maize, the total water footprint of winter wheat increased slightly, primarily due to increases in the grey water footprint of winter wheat with increases of nitrogen rate applied to summer maize. 

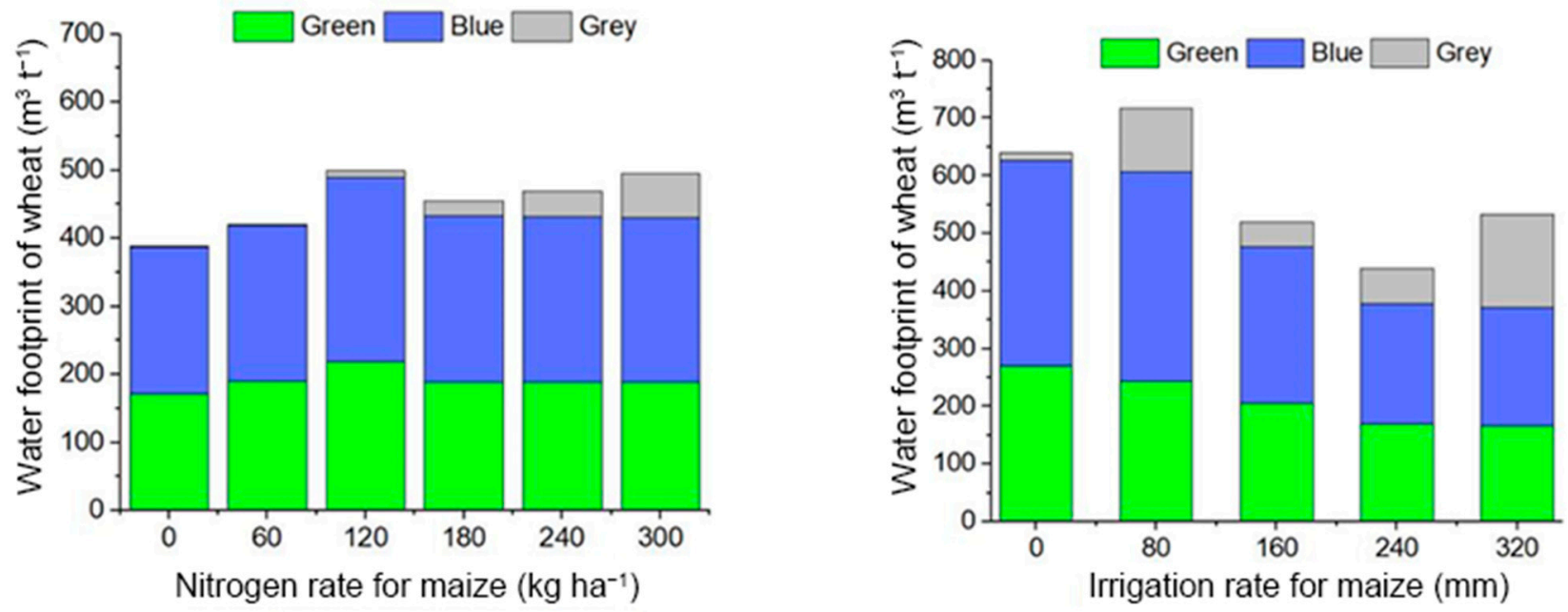

Figure 5. The water footprint of winter wheat: response to nitrogen rate and irrigation applied to summer maize from 1967 to 2015 . Winter wheat was planted with $240 \mathrm{~kg} \mathrm{ha}^{-1}$ of nitrogen rate and $160 \mathrm{~mm}$ of irrigation.

The green, blue and total water footprint of winter wheat declined under increasing levels of irrigation applied to summer maize. The green, blue and total water footprint was higher when maize irrigation was less than $80 \mathrm{~mm}$, because grain yield of winter wheat was decreased by drought stress. When the irrigation amount in maize increased from 80 to $240 \mathrm{~mm}$, the green, blue, grey and total water footprint of winter wheat declined.

\subsection{Managements Factors Influencing Average Water Footprint}

A correlation analysis was conducted among different management factors related to crop yield and water footprint. The results showed that the annual water footprint was significantly positively correlated to annual nitrogen rate $(R=0.90, p<0.001)$, but not related to annual irrigation (Table 5). Grain yield and $\mathrm{N}$ leaching of both wheat and maize showed positive correlation to annual water footprint. The structural equation model (SEM) showed that the positive effect of nitrogen on annual water footprint was mainly through its positive effect on $\mathrm{N}$ leaching of wheat and maize (Figure 6). Although the annual water footprint was not significantly correlated to annual irrigation, the SEM showed that irrigation also had an effect on the annual water footprint by $\mathrm{N}$ leaching of maize (Path coefficient $=0.33, p<0.001$ ). Note that grain yield of wheat and maize, which showed positive correlation to annual water footprint, was eliminated from the SEM as a significant indicator of annual water footprint. The SEM also showed that irrigation did not directly affect annual water footprint (path coefficient $=0.02, p>0.05$ ). All the results indicated that the annual water footprint in North China Plain was more sensitive to the grey water footprint.

Table 5. The correlation coefficients between management practices and water footprint properties.

\begin{tabular}{|c|c|c|c|c|c|c|c|c|}
\hline & \multirow{2}{*}{ Nitrogen } & \multirow{2}{*}{ Irrigation } & \multicolumn{3}{|c|}{ Wheat } & \multicolumn{3}{|c|}{ Maize } \\
\hline & & & Yield & ET & N Leaching & Yield & ET & N Leaching \\
\hline Wheat yield & 0.29 & $0.86^{* * *}$ & 1.00 & & & & & \\
\hline Wheat ET & 0.16 & $0.91^{* * *}$ & $0.96^{* * *}$ & 1.00 & & & & \\
\hline $\begin{array}{l}\text { Wheat N } \\
\text { leaching }\end{array}$ & $0.62 * * *$ & 0.03 & 0.27 & 0.19 & 1.00 & & & \\
\hline Maize yield & $0.43 * *$ & $0.55 * * *$ & $0.56^{* * *}$ & $0.49^{* *}$ & 0.06 & 1.00 & & \\
\hline Maize ET & 0.20 & $0.79^{* * *}$ & $0.67^{* * *}$ & $0.66^{* * *}$ & -0.09 & $0.85^{* * *}$ & 1.00 & \\
\hline $\begin{array}{l}\text { Maize N } \\
\text { Leaching }\end{array}$ & $0.90^{* * *}$ & 0.29 & $0.45^{* *}$ & 0.33 * & 0.50 ** & $0.68^{* * *}$ & $0.50 * *$ & 1.00 \\
\hline Total WF & $0.90^{* * *}$ & 0.18 & 0.35 * & 0.21 & $0.65^{* * *}$ & $0.49^{* *}$ & 0.30 & $0.90^{* * *}$ \\
\hline
\end{tabular}

${ }^{*} p<0.05,{ }^{* *} p<0.01,{ }^{* * *} p<0.001$. ET, evapotranspiration. 


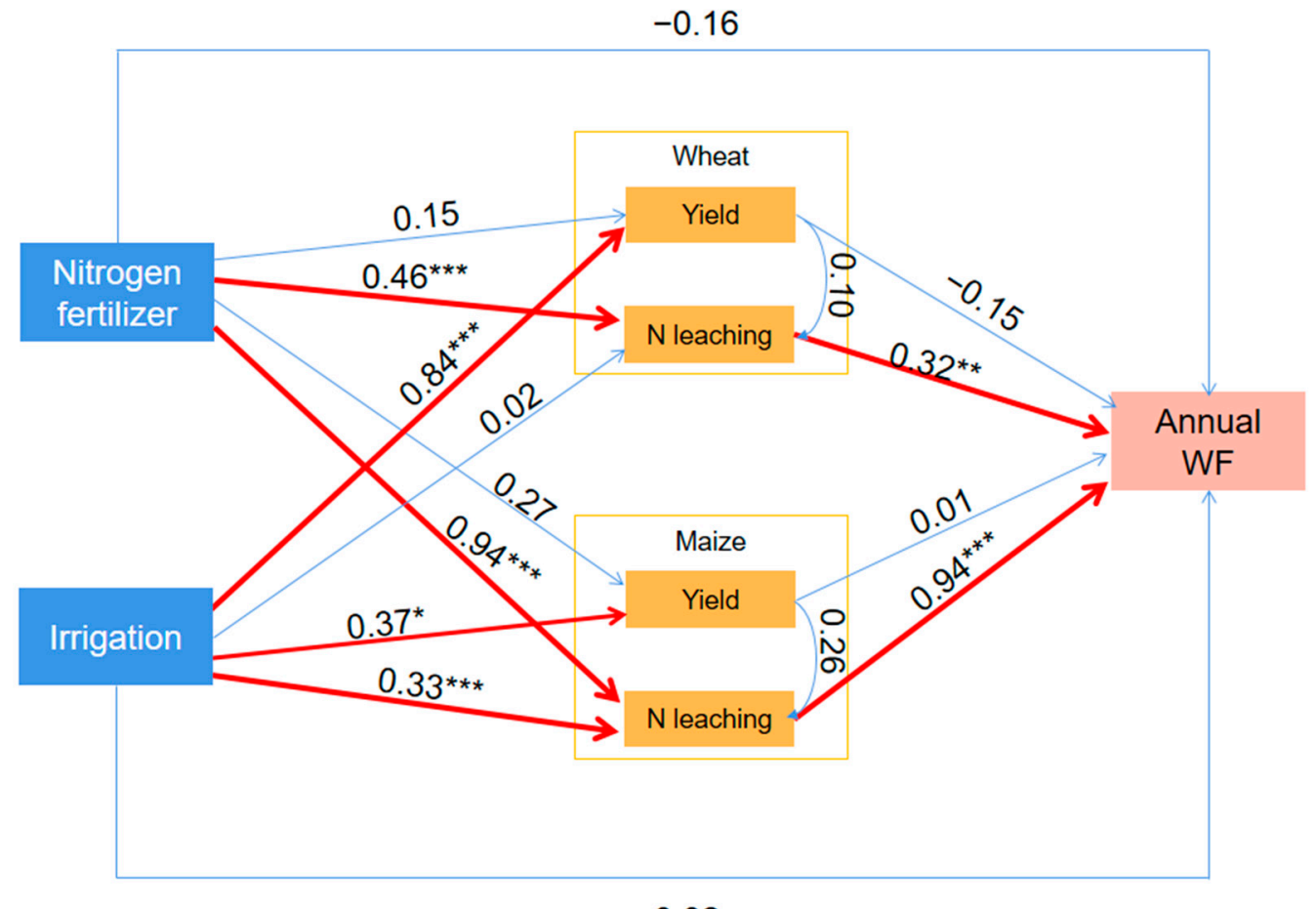

0.02

Figure 6. A structural equation model of management effects on water footprint. Red arrows represent significant positive pathways, and blue arrows indicate insignificant pathways. Bold numbers indicate the standard path coefficient. ${ }^{*} p<0.05,{ }^{* *} p<0.01,{ }^{* * *} p<0.001$; root mean square of approximation $($ RMSEA $)=0.388, p=0.000$.

\section{Discussion}

\subsection{Evaluation of Methodology}

Benchmarks for the water footprint of crop production can serve as a reference for setting water footprint reduction targets [17]. Lu et al. [53] studied the water footprint over 35 years at the field level in the North China Plain, and indicated that the water footprint of winter wheat was $890 \mathrm{~m}^{3} \mathrm{t}^{-1}$. Zhuo et al. [17] explored the water footprint of winter wheat at the national level and suggested that the average water footprint of winter wheat was $841 \mathrm{~m}^{3} \mathrm{t}^{-1}$ for humid areas in China. Mekonnen and Hoekstra [27] systematically analyzed the crop water footprint at a 5 by 5 min spatial resolution globally based on FAOSTAT data (1996-2005), and reported that the water footprint of maize in Hebei, the main part of NCP, was $1218 \mathrm{~m}^{3} \mathrm{t}^{-1}$. Lu et al. [53] reported that the water footprint of maize in NCP was $700 \mathrm{~m}^{3} \mathrm{t}^{-1}$. This range of values was probably because there were differences in soil properties, weather, crop characteristics, and leaching-runoff fraction of nitrogen, etc., among the sites of different studies [8]. Note that Lu et al. [53] used $4.35 \%$ of nitrogen fertilizer to estimate the grey water footprint, but Mekonnen and Hoekstra [27] used $10 \%$. A fixed percentage of nitrogen fertilizer to estimate the grey water footprint is reasonable when estimated at the regional level, but may be inappropriate if the aim of the study is to optimize management practices at specific sites [25]. This study showed that the CERES-Wheat and -Maize model can simulate the productivity, water and nitrogen balance of winter wheat and summer maize rotation at the study site. Thus, the DSSAT model can be used to investigate the response of wheat and maize water footprint to irrigation and nitrogen. This study provides an example of such analysis for a representative site, through combination of field measurement data, cropping systems modelling, and scenario analysis.

\subsection{The Effect of Managements on Water Footprint}

The water footprint includes direct and indirect water consumption, as well as their environmental effects. The quantification of water footprint of crop production will con- 
tribute to the assessment of agricultural water utilization. The winter wheat-summer maize double cropping is a main rotation system in NCP. We found that the irrigation and N management strategies impact the water footprints for both the maize and wheat crops. Thus, integrated research on water footprint of wheat and maize is necessary in NCP.

The results of this study showed a significantly positive relationship between annual water footprint and grain yield (Table 5). Lu et al. [53] indicated that the increase in farm inputs, such as nitrogen fertilizer and irrigation, contributed greatly to the increase of water footprint in NCP. This means that increase in grain yield was accompanied by an increase in the water footprint. In our study, we found that the positive effect of nitrogen fertilizer and irrigation on annual water footprint was mainly through its positive effect on $\mathrm{N}$ leaching in both wheat and maize (Figure 6). Liu et al. [54] and Lu et al. [55] reported the decreasing marginal benefit of nitrogen and irrigation resulting in smaller yield increase. Thus, excessive nitrogen accumulates in soil, and the residual $\mathrm{N}$ moves out of root zone when there is higher rainfall or full irrigation. According to the water footprint theory, grey water footprint refers to the volume of water that is required to assimilate waste nutrients based on existing ambient water quality standards $[27,56]$. The results of this study showed that the annual water footprint in North China Plain was very sensitive to grey water footprint. These results suggested that reducing the grey water footprint was a way to decrease the annual water footprint in NCP.

In our study, we found that the water footprint of wheat increased with the increase of nitrogen rate, but the increments of total and grey water footprint of maize by increasing nitrogen fertilizer in maize were higher than those of wheat. This was due to higher $\mathrm{NO}_{3}-\mathrm{N}$ leaching that occurred in the maize season than that in wheat season due to more leaching out of the root zone under higher rainfall occurring during summer [57]. Li et al. [58] reported that the average $\mathrm{NO}_{3}-\mathrm{N}$ leaching losses during wheat-maize seasons were 6 and $58 \mathrm{~kg} \mathrm{NO}_{3}-\mathrm{N} \mathrm{ha}^{-1}$ year $^{-1}$ for 200 and $400 \mathrm{~kg} \mathrm{~N} \mathrm{ha}^{-1}$ year $^{-1}$ of the nitrogen fertilization, respectively. This study showed similar result to those in previous studies, with the annual average $\mathrm{NO}_{3}-\mathrm{N}$ leaching losses 2.5 and $57.2 \mathrm{~kg} \mathrm{NO}_{3}-\mathrm{N} \mathrm{ha}^{-1}$ year ${ }^{-1}$ for the nitrogen rates 240 and $420 \mathrm{~kg} \mathrm{~N} \mathrm{ha}^{-1}$ year $^{-1}$, respectively. The results of this study also showed that the grey water footprint of maize increased linearly when the nitrogen rate applied to maize exceeded $60 \mathrm{~kg} \mathrm{ha}^{-1}$. A similar result of increasing $\mathrm{N}$ leaching of maize due to increased nitrogen in NCP was obtained by Wang et al. [59]. The water footprint of summer maize was also significantly affected by the nitrogen rate applied to winter wheat (Figure 2). Previous research indicated that because of limited rainfall and irrigation, $\mathrm{N}$ applied during the winter wheat season primarily accumulated in soil, and $\mathrm{NO}_{3}-\mathrm{N}$ leaching out of the root zone is negligible under limited irrigation scheduling. However, this residual $\mathrm{N}$ is highly susceptible to leaching out of the root zone during the summer maize season due to higher rainfall [60-62]. These results indicated that farmers should first try to reduce the nitrogen rate applied during the maize season, but the nitrogen rate applied to wheat should also be considered.

The results of this study showed that the blue, grey and total water footprint of wheat and maize increased with an increase in irrigation. The increase in water footprint with increasing irrigation was higher than that with increasing nitrogen for wheat. This means that soil water becomes more limiting in the water footprint of wheat than nitrogen. It can also be seen in Figure 5 that residual nitrogen and water of maize affected the water footprint of wheat. For instance, when the irrigation amount for maize increased from 80 to $240 \mathrm{~mm}$, the green, blue, grey, and total water footprint of wheat significantly declined. However, the total water footprint of wheat increased slowly with increases in the nitrogen rate for maize.

The correlation analysis indicated that grain yields of wheat and maize were positively correlated to irrigation. Thus, the grain yields of wheat and maize increased with increasing irrigation. The positive effect of irrigation on the annual water footprint was mainly through its positive effect on $\mathrm{N}$ leaching in maize, but not on grain yield and $\mathrm{N}$ leaching in wheat. Irrigation of $160 \mathrm{~mm}$ for wheat can maintain a high grain yield, and furthermore, $70 \%$ of the 
annual precipitation typically occurring in the maize season will satisfy the water demand of maize in most years, so the irrigation amount during maize season can likely be reduced in order to reduce the annual water footprint in reduced irrigation cropping systems.

\subsection{Optimization of Fertilizer Strategies}

Chen et al. [63] and Ma et al. [64] reported that to achieve maximum water productivity, approximately 1-3 irrigations were recommended for wheat in different weather seasons, and 0-2 irrigations were recommended for maize in the NCP. Typical production practices in the NCP include 3 irrigations for winter wheat and 1-2 irrigations for maize [65]. China is targeting a $30 \%$ reduction in irrigation and zero growth in the use of chemical fertilizers and pesticides by 2020 to avoid further damage to the environment [66]. Thus, it is urgent to explore reduced irrigation strategies that will maintain yield and further increase water use efficiency. Sun et al. [67] reported that minimum irrigation applied at sowing for wheat and maize will result in lower crop productivity and increased inter-annual variability in crop yields. This study showed that $160 \mathrm{~mm}$ irrigation produced a minimum total water footprint for wheat. However, because soil water content was significantly lower after wheat harvest, maize was irrigated immediately after sowing to ensure seed germination. Therefore, irrigation applied at sowing and jointing for winter wheat and at sowing for maize may be the best water-saving strategy.

In order to explore a further reduction of the water footprint in NCP, we simulated the response of wheat and maize to different nitrogen treatments under water-saving irrigation conditions. Table 6 shows that the grain yield and marginal return of both wheat and maize decreased with the reduction in nitrogen rate of wheat. This response was significantly affected by maize nitrogen application. Increasing the nitrogen rate in maize contributes to an increase in the grain yield and marginal return of wheat. Winter wheat can grow much deeper roots than maize. Thus, the deep-rooted winter wheat could be able to recover nitrogen from deeper soil layers than maize. Note that the loss in yield and marginal return of winter wheat due to reduce $\mathrm{N}$ rate cannot be compensated by increasing the maize $\mathrm{N}$ rate, because the recovery of residual $\mathrm{N}$ was so much lower (only $4.9 \%$ to $8.7 \%$ ) for winter wheat [68]. This can also be seen in Table 6. For instance, treatment 3 produced $88.87 \%$ of the grain yield of treatment 7 , although the $N$ rates of treatment 3 and 7 both were $300 \mathrm{~kg} \mathrm{ha}^{-1}$.

Table 6. Ranking fertilizer strategies in order of performance using different criteria.

\begin{tabular}{|c|c|c|c|c|c|c|c|c|c|c|c|c|c|c|c|c|c|}
\hline \multirow{3}{*}{ No } & \multicolumn{8}{|c|}{ Wheat } & \multicolumn{8}{|c|}{ Maize } & \multirow{3}{*}{ Rs } \\
\hline & \multicolumn{2}{|c|}{ Yield } & \multicolumn{2}{|c|}{$\mathrm{CV}$} & \multicolumn{2}{|c|}{ WF } & \multicolumn{2}{|c|}{ Return } & \multicolumn{2}{|c|}{ Yield } & \multicolumn{2}{|c|}{$\mathrm{CV}$} & \multicolumn{2}{|c|}{ WF } & \multicolumn{2}{|c|}{ Return } & \\
\hline & tha $a^{-1}$ & $\mathbf{R}$ & $\%$ & $\mathbf{R}$ & $m^{3} t^{-1}$ & $\mathbf{R}$ & $\$ h^{-1}$ & $\mathbf{R}$ & tha $a^{-1}$ & $\mathbf{R}$ & $\%$ & $\mathbf{R}$ & $m^{3} t^{-1}$ & $\mathbf{R}$ & $\$ h^{-1}$ & $\mathbf{R}$ & \\
\hline 1 & 4.85 & 9 & 30.42 & 7 & 670.2 & 8 & 1084.5 & 9 & 6.22 & 9 & 16.60 & 1 & 764.8 & 6 & 1843.9 & 9 & 58 \\
\hline 2 & 4.93 & 8 & 32.33 & 8 & 659.8 & 7 & 1121.8 & 8 & 7.31 & 8 & 19.11 & 2 & 699.3 & 4 & 2184.2 & 8 & 53 \\
\hline 3 & 5.51 & 7 & 33.40 & 9 & 604.0 & 5 & 1330.6 & 7 & 8.00 & 6 & 22.03 & 6 & 683.6 & 3 & 2379.5 & 6 & 49 \\
\hline 4 & 5.81 & 6 & 25.50 & 1 & 525.2 & 3 & 1385.9 & 6 & 7.40 & 7 & 22.51 & 9 & 726.3 & 5 & 2270.8 & 7 & 44 \\
\hline $\begin{array}{l} \pm \\
5\end{array}$ & 6.03 & 5 & 28.14 & 5 & 520.9 & 2 & 1466.0 & 5 & 8.23 & 5 & 21.59 & 4 & 662.3 & 2 & 2514.4 & 5 & 33 \\
\hline 6 & 6.45 & 3 & 28.48 & 6 & 579.5 & 4 & 1616.9 & 3 & 8.45 & 3 & 22.42 & 8 & 800.0 & 7 & 2542.6 & 4 & 38 \\
\hline 7 & 6.20 & 4 & 27.77 & 4 & 515.1 & 1 & 1471.6 & 4 & 8.42 & 4 & 21.43 & 3 & 655.4 & 1 & 2637.0 & 1 & 22 \\
\hline 8 & 6.63 & 2 & 26.79 & 3 & 615.3 & 6 & 1626.1 & 2 & 8.53 & 1 & 21.96 & 5 & 873.4 & 8 & 2622.6 & 2 & 29 \\
\hline 9 & 6.83 & 1 & 25.73 & 2 & 795.9 & 9 & 1699.0 & 1 & 8.49 & 2 & 22.31 & 7 & 1253.5 & 9 & 2556.4 & 3 & 34 \\
\hline
\end{tabular}

1 W60 + M60; 2, W60 + M150; 3, W60 + M240; 4, W150 + M60; 5, W150 + M150; 6, W150 + M240; 7, W240 + M60 8, W240 + M150; 9, W240 + M240. W, wheat; M, maize. 60, 150 and 240 is nitrogen rate $\left(\mathrm{kg} \mathrm{ha}^{-1}\right)$. CV, coefficient of variation. WF, water footprint; $R$, rank. Rs, the sum rank of all parameters. US $\$=6.6$ Chinese Yuan. The prices for land preparation and sowing were: wheat grain $\left(0.36 \$ \mathrm{~kg}^{-1}\right)$, water power $\left(\$ 0.08 \mathrm{~m}^{-3}\right)$, ploughing $\left(\$ 68 \mathrm{ha}^{-1}\right)$, rotary $\left(\$ 45 \mathrm{ha}^{-1}\right)$, wheat sowing $\left(\$ 56 \mathrm{ha}^{-1}\right)$, wheat seeds $\left(\$ 0.52 \mathrm{~kg}^{-1}\right)$, herbicides and pesticides $\left(\$ 23 \mathrm{ha}^{-1}\right)$, harvest $\left(\$ 145 \mathrm{ha}^{-1}\right), \mathrm{N}$ fertilizer $\left(\$ 0.59 \mathrm{~kg}^{-1}\right), \mathrm{P}_{2} \mathrm{O}_{5}$ fertilizer $\left(0.52 \mathrm{~kg}^{-1}\right)$, and labor price $\left(\$ 8\right.$ day $\left.^{-1}\right)$.

The water footprint of wheat and maize decreased with decreasing nitrogen rates. The application of $\mathrm{N} 240 \mathrm{~kg} \mathrm{ha}^{-1}$ to wheat followed by $60 \mathrm{~kg} \mathrm{ha}^{-1}$ to maize produced the minimum water footprint for the wheat-maize rotation $\left(R_{\text {wheat }}+R_{\text {maize }}=2\right)$. This would likely be the best strategy if the management objective was to have a lower water footprint. Table 5 also shows that different performance criteria led to different ranking. Based on 
grain yield and marginal return, nitrogen application of $240 \mathrm{~kg} \mathrm{ha}^{-1}$ to wheat followed by 150 and $240 \mathrm{~kg} \mathrm{ha}^{-1}$ to maize were the best systems $\left(R_{\text {wheat }}+R_{\text {maize }}=3\right)$. Yield stability of cropping systems may be more important than yield maximization [69]. According to this criterion, applying $240 \mathrm{~kg} \mathrm{ha}^{-1}$ to wheat followed by $60 \mathrm{~kg} \mathrm{ha}^{-1}$ to maize was the most stable system $\left(R_{\text {wheat }}+R_{\text {maize }}=7\right)$. Taking grain yield, marginal return and water footprint into consideration, the sequence analysis indicated that the application of $\mathrm{N} 240 \mathrm{~kg} \mathrm{ha}^{-1}$ to wheat followed by $60 \mathrm{~kg} \mathrm{ha}^{-1}$ to maize (No. 7) produced the minimum water footprint and higher grain yield and marginal return. Zhao et al. [4] suggested that application of $150 \mathrm{~kg} \mathrm{ha}^{-1}$ to wheat followed by $180 \mathrm{~kg} \mathrm{ha}^{-1}$ to maize can maintain the potential productivity of grain yield and have the minimum impact on the environment in NCP using the APSIM model. Liu et al. [70] reported that the recommended nitrogen application rate was $107 \mathrm{~kg} \mathrm{ha}^{-1}$ for wheat and $99 \mathrm{~kg} \mathrm{ha}^{-1}$ for maize. Soil mineral $\mathrm{N}$ content is a critical guide to maximize maize yield, and a minimum soil $\mathrm{N}$ concentration of $6.1 \mathrm{mg} \mathrm{kg}^{-1}$ was recommended at sowing in the rotation system [71]. In this study, the results also showed the annual water footprint in North China Plain was very sensitive to grey water footprint of summer maize. The grey water footprint of maize increased linearly when the nitrogen rate applied to maize exceeded $60 \mathrm{~kg} \mathrm{ha}^{-1}$. The application of $240 \mathrm{~kg} \mathrm{ha}^{-1}$ to wheat followed by $60 \mathrm{~kg} \mathrm{ha}^{-1}$ to maize (No. 7) may be the best management strategy.

\section{Conclusions}

The winter wheat-summer maize double cropping is the primary cropping system in the North China Plain (NCP), and thus integrated research on the water footprint of wheat and maize is necessary. In this study, the DSSAT-CERES-Wheat and -Maize model was used to evaluate grain yield and water footprint in the double cropping system of winter wheat and summer maize based on 48 years of historical weather data in NCP. It was found that the increase in $\mathrm{N}$ inputs contributed greatly to the increase in water footprint, mainly through the grey water footprint. Management practices (i.e., $\mathrm{N}$ application) in winter wheat affected the water footprint of summer maize. The response of the water footprint of wheat to nitrogen and irrigation was different from that of maize. Based on the simulation results, $240 \mathrm{~mm}$ water-saving irrigation with $300 \mathrm{~kg} \mathrm{ha}^{-1}$ of nitrogen (240 kg N ha ${ }^{-1}$ for wheat and $60 \mathrm{~kg} \mathrm{~N} \mathrm{ha}^{-1}$ for maize) can maintain higher grain yield and have a lower water footprint and thus, lower impact on the environment. For the NCP, the water footprint of wheat and maize can be improved by following improved irrigation and nitrogen management strategies.

Author Contributions: Methodology, D.Z.; software, D.Z.; validation, D.Z., D.L. and W.D.B.; formal analysis, D.Z. and D.L.; investigation, H.L. and H.W.; data curation, D.L. and J.L.; writing-original draft preparation, D.Z.; writing - review and editing, D.L., R.L. and H.J.; supervision, Y.L. and W.D.B. All authors have read and agreed to the published version of the manuscript.

Funding: This research was funded by China Agriculture Research System (CARS-03-05), by National Science and Technology Support Program of China "The science and technology engineering for grain bumper harvest" (2013BAD07B05), and by National Key Special Program of China "Technological innovation for grain bumper harvest and high income" (2017YFD0300909), and by Natural Science Foundation of Yangling Vocational and Technical College (BG202005), and by National Key Research and Development Program of China (2021YFD1901004-2), and by the National Institute of Food and Agriculture, U.S. Department of Agriculture, Hatch project (ALA014-1-16016), and by the China Scholarship Council.

Institutional Review Board Statement: Not applicable.

Informed Consent Statement: Not applicable.

Data Availability Statement: All data supporting the results of this study are included in the manuscript and datasets are available upon request. 
Acknowledgments: We are grateful to the laboratory staff and the undergraduate students Qin Fang, Shuai Cui and Tian Lv of the Hebei Agricultural University for their contributions. The valuable comments of the editor and anonymous reviewers are greatly acknowledged.

Conflicts of Interest: The authors declare no conflict of interest.

\section{References}

1. Wang, J.; Wang, E.L.; Yang, X.G.; Zhang, F.S.; Yin, H. Increased yield potential of wheat-maize cropping system in the North China Plain by climate change adaptation. Clim. Change 2012, 113, 825-840. [CrossRef]

2. Carberry, P.S.; Liang, W.L.; Twomlow, S.; Holzworth, D.P.; Dimes, J.P.; McClelland, T.; Huth, N.I.; Chen, F.; Hochman, Z.; Keating, B.A. Scope for improved eco-efficiency varies among diverse cropping systems. Proc. Natl. Acad. Sci. USA 2013, 110, 8381-8386. [CrossRef] [PubMed]

3. Chinese Statistical Bureau. China Statistical Yearbook; China Statistics Press: Beijing, China, 2016.

4. Zhao, Z.G.; Qin, X.; Wang, E.L.; Carberry, P.; Zhang, Y.H.; Zhou, S.L.; Zhang, X.Y.; Hu, C.S.; Wang, Z.M. Modelling to increase the eco-efficiency of a wheat-maize double cropping system. Agric. Ecosyst. Environ. 2015, 210, 36-46. [CrossRef]

5. Zhao, J.; Zhang, X.P.; Yang, Y.D.; Zang, H.D.; Yan, P.; Meki, M.N.; Doro, L.; Sui, P.; Jeong, J.; Zeng, Z.H. Alternative cropping systems for groundwater irrigation sustainability in the North China Plain. Agric. Water Manag. 2021, 250, 106867. [CrossRef]

6. Xu, Y.J.; Huang, K.; Yu, Y.J.; Wang, X.M. Changes in water footprint of crop production in Beijing from 1978 to 2012 : A logarithmic mean Divisia index decomposition analysis. J. Clean. Prod. 2015, 87, 180-187. [CrossRef]

7. Darbyshire, R.; Crean, E.; Dunn, T.; Dunn, B. Predicting panicle initiation timing in rice grown using water efficient systems. Field Crops Res. 2019, 239, 159-164. [CrossRef]

8. Zhai, Y.J.; Tan, X.F.; Ma, X.T.; An, M.G.; Zhao, Q.L.; Shen, X.X.; Hong, J.L. Water footprint analysis of wheat production. Ecol. Indic. 2019, 102, 95-102. [CrossRef]

9. Sun, Y.Y.; Zhi, Y.; Zhao, Y.W. Indirect effects of carbon taxes on water conservation: A water footprint analysis for China. J. Environ. Manag. 2021, 279, 111747. [CrossRef]

10. Hoekstra, A.Y.; Chapagain, A.K.; Aldaya, M.M.; Mekonnen, M.M. The Water Footprint Assessment Manual: Setting the Global Standard; Earthscan: London, UK, 2011.

11. Chapagain, A.K.; Hoekstra, A.Y.; Savenije, H.H.G.; Gautam, R. The water footprint of cotton consumption: An assessment of the impact of worldwide consumption of cotton products on the water resources in the cotton producing countries. Ecol. Econ. 2006, 60, 186-203. [CrossRef]

12. Chapagain, A.K.; Orr, S. An improved water footprint methodology linking global consumption to local water resources: A case of Spanish tomatoes. J. Environ. Manag. 2009, 90, 1219-1228. [CrossRef]

13. Morillo, J.G.; Diaz, J.A.R.; Camacho, E.; Montesinos, P. Linking water footprint accounting with irrigation management in high value crops. J. Clean. Prod. 2015, 87, 594-602. [CrossRef]

14. Scarpare, F.V.; Hernandes, T.A.D.; Ruiz-Correa, S.T.; Kolln, O.T.; Gava, G.J.D.C.; Santos, L.N.S.D.; Victoria, R.L. Sugarcane water footprint under different management practices in Brazil: Tiete/Jacare watershed assessment. J. Clean. Prod. 2016, 112, 4576-4584. [CrossRef]

15. Bocchiola, D.; Nana, E.; Soncini, A. Impact of climate change scenarios on crop yield and water footprint of maize in the Po valley of Italy. Agric. Water Manag. 2013, 116, 50-61. [CrossRef]

16. Pellegrini, G.; Ingrao, C.; Carnposeo, S.; Tricase, C.; Conto, F.; Huisingh, D. Application of water footprint to olive growing systems in the Apulia region: A comparative assessment. J. Clean. Prod. 2016, 112, 2407-2418. [CrossRef]

17. Zhuo, L.; Mekonnen, M.M.; Hoekstra, A.Y. Benchmark levels for the consumptive water footprint of crop production for different environmental conditions: A case study for winter wheat in China. Hydrol. Earth Syst. Sc. 2016, 20, 4547-4559. [CrossRef]

18. Finogenova, N.; Dolganova, I.; Berger, M.; Nunez, M.; Blizniukova, D.; Mueller-Frank, A.; Finkbeiner, M. Water footprint of German agricultural imports: Local impacts due to global trade flows in a fifteen-year perspective. Sci. Total Environ. 2019, 662, 521-529. [CrossRef]

19. Gleeson, T.; Wada, Y.; Bierkens, M.F.P.; van Beek, L.P.H. Water balance of global aquifers revealed by groundwater footprint. Nature 2012, 488, 197-200. [CrossRef]

20. Hoekstra, A.Y.; Mekonnen, M.M. The water footprint of humanity. Proc. Natl. Acad. Sci. USA 2012, 109, 3232-3237. [CrossRef]

21. Zhao, X.; Liao, X.W.; Chen, B.; Tillotson, M.R.; Guo, W.; Li, Y.P. Accounting global grey water footprint from both consumption and production perspectives. J. Clean. Prod. 2019, 225, 963-971. [CrossRef]

22. Mekonnen, M.M.; Hoekstra, A.Y. Water footprint benchmarks for crop production: A first global assessment. Ecol. Indic. 2014, 46, 214-223. [CrossRef]

23. Chukalla, A.D.; Krol, M.S.; Hoekstra, A.Y. Green and blue water footprint reduction in irrigated agriculture: Effect of irrigation techniques, irrigation strategies and mulching. Hydrol. Earth Syst. Sc. 2015, 19, 4877-4891. [CrossRef]

24. Brueck, H.; Lammel, J. Impact of fertilizer N application on the grey water footprint of winter wheat in a NW-European temperate climate. Water 2016, 8, 356. [CrossRef]

25. Muratoglu, A. Grey water footprint of agricultural production: An assessment based on nitrogen surplus and high-resolution leaching runoff fractions in Turkey. Sci. Total Environ. 2020, 742, 140553. [CrossRef] [PubMed] 
26. Zeng, Z.; Liu, J.; Koeneman, P.H.; Zarate, E.; Hoekstra, A.Y. Assessing water footprint at river basin level: A case study for the Heihe River Basin in Northwest China. Hydrol. Earth Syst. Sc. 2012, 16, 2771-2781. [CrossRef]

27. Mekonnen, M.M.; Hoekstra, A.Y. The green, blue and grey water footprint of crops and derived crop products. Hydrol. Earth Syst. Sc. 2011, 15, 1577-1600. [CrossRef]

28. Zhang, Z.Y.; Yang, H.; Shi, M.J. Analyses of water footprint of Beijing in an interregional input-output framework. Ecol. Econ. 2011, 70, 2494-2502. [CrossRef]

29. Zhang, C.; Anadon, L.D. A multi-regional input-output analysis of domestic virtual water trade and provincial water footprint in China. Ecol. Econ. 2014, 100, 159-172. [CrossRef]

30. Hoogenboom, G.; Jones, J.W.; Wilkens, P.W.; Porter, C.H.; Boote, K.J.; Hunt, L.D.; Singh, U.; Lizaso, J.I.; White, J.M.; Uryasev, O. Decision Support System for Agrotechnology Transfer (DSSAT) Version 4.6; DSSAT Foundation: Prosser, WA, USA, 2015.

31. Batchelor, W.D.; Basso, B.; Paz, J.O. Examples of strategies to analyze spatial and temporal yield variability using crop models. Eur. J. Agron. 2002, 18, 141-158. [CrossRef]

32. Li, Y.C.; Huang, H.P.; Ju, H.; Lin, E.D.; Xiong, W.; Han, X.; Wang, H.R.; Peng, Z.P.; Wang, Y.Q.; Xu, J.W.; et al. Assessing vulnerability and adaptive capacity to potential drought for winter-wheat under the RCP 8.5 scenario in the Huang-Huai-Hai Plain. Agric. Ecosyst. Environ. 2015, 209, 125-131. [CrossRef]

33. Awan, Z.A.; Khaliq, T.; Akhtar, M.M.; Imran, A.; Irfan, M.; Ahmed, M.J.; Ahmad, A. Building climate-resilient cotton production system for changing climate scenarios using the DSSAT model. Sustainability 2021, 13, 10495. [CrossRef]

34. Jiang, Y.W.; Zhang, L.H.; Zhang, B.Q.; He, C.S.; Jin, X.; Bai, X. Modeling irrigation management for water conservation by DSSAT-maize model in arid northwestern China. Agric. Water Manag. 2016, 177, 37-45. [CrossRef]

35. Xiang, Z.; Bailey, R.T.; Nozari, S.; Husain, Z.; Kisekka, I.; Sharda, V.; Gowda, P. DSSAT-MODFLOW: A new modeling framework for exploring groundwater conservation strategies in irrigated areas. Agr. Water Manag. 2020, 232, 103033. [CrossRef]

36. Si, Z.Y.; Zain, M.; Li, S.; Liu, J.M.; Liang, Y.P.; Gao, Y.; Duan, A.W. Optimizing nitrogen application for drip-irrigated winter wheat using the DSSAT-CERES-Wheat model. Agr. Water Manag. 2021, 244, 106592. [CrossRef]

37. Ren, X.M.; Sun, D.B.; Wang, Q.S. Modeling the effects of plant density on maize productivity and water balance in the Loess Plateau of China. Agric. Water Manag. 2016, 171, 40-48. [CrossRef]

38. Zhang, D.; Wang, H.G.; Li, D.X.; Li, H.R.; Ju, H.; Li, R.Q.; Batchelor, W.D.; Li, Y.M. DSSAT-CERES-wheat model to optimize plant density and nitrogen best management practices. Nutr. Cycl. Agroecosys. 2019, 114, 19-32. [CrossRef]

39. Li, Z.T.; Yang, J.Y.; Drury, C.F.; Hoogenboom, G. Evaluation of the DSSAT-CSM for simulating yield and soil organic C and N of a long-term maize and wheat rotation experiment in the Loess Plateau of Northwestern China. Agric. Syst. 2015, 135, 90-104. [CrossRef]

40. Araya, A.; Kisekka, I.; Gowda, P.H.; Prasad, P.V.V. Evaluation of water-limited cropping systems in a semi-arid climate using DSSAT-CSM. Agric. Syst. 2017, 150, 86-98. [CrossRef]

41. Ventrella, D.; Giglio, L.; Charfeddine, M.; Dalla Marta, A. Consumptive use of green and blue water for winter durum wheat cultivated in Southern Italy. Ital. J. Agrometeorol. 2015, 20, 33-44.

42. Yesilköy, S.; Saylan, L. Yields and water footprints of sunflower and winter wheat under different climate projections. J. Clean. Prod. 2021, 2, 126780. [CrossRef]

43. Lv, L.H.; Dong, Z.Q.; Zhang, J.T.; Zhang, L.H.; Liang, S.B.; Jia, X.L.; Yao, H.P. Effect of water and nitrogen on yield and nitrogen utilization of winter wheat and summer maize. Sci. Agri. Sin. 2014, 47, 3839-3849.

44. Zhang, J.T.; Chen, Q.Y.; Lv, L.H.; Shen, H.P.; Jia, X.L.; Liang, S.P. Optimum combination of irrigation and nitrogen for high yield and nitrogen use efficiency in winter wheat and summer maize rotation system. J. Plant Nutr. Fert. 2016, 22, 886-896. [CrossRef]

45. Jones, J.W.; Hoogenboom, G.; Porter, C.H.; Boote, K.J.; Batchelor, W.D.; Hunt, L.A.; Wilkens, P.W.; Singh, U.; Gijsman, A.J.; Ritchie, J.T. The DSSAT cropping system model. Eur. J. Agron. 2003, 18, 235-265. [CrossRef]

46. Yang, Y.H.; Watanabe, M.; Zhang, X.Y.; Zhang, J.Q.; Wang, Q.X.; Hayashi, S. Optimizing irrigation management for wheat to reduce groundwater depletion in the piedmont region of the Taihang Mountains in the North China Plain. Agric. Water Manag. 2006, 82, 25-44. [CrossRef]

47. Chen, C.; Wang, E.L.; Yu, Q. Modeling wheat and maize productivity as affected by climate variation and irrigation supply in North China Plain. Agron. J. 2010, 102, 1037-1049. [CrossRef]

48. Willmott, C.J. Some Comments on the Evaluation of Model Performance. Bull. Am. Meteorol. Soc. 1982, 63, 1309-1313. [CrossRef]

49. Yang, J.; Greenwood, D.J.; Rowell, D.L.; Wadsworth, G.A.; Burns, I.G. Statistical methods for evaluating a crop nitrogen simulation model, N_ABLE. Agric. Syst. 2000, 64, 37-53. [CrossRef]

50. Jamieson, P.D.; Porter, J.R.; Wilson, D.R. A test of the computer-simulation model Archwheat1 on wheat crops grown in New-Zealand. Field Crops Res. 1991, 27, 337-350. [CrossRef]

51. De Mendiburu, F. Agricolae: Statistical Procedures for Agricultural Research; R Team: Vienna, Austria, 2012; Volume 1, pp. 2-4.

52. Rosseel, Y. Lavaan: An R Package for Structural Equation Modeling. J. Stat. Softw. 2012, 48, 1-36. [CrossRef]

53. Lu, Y.; Zhang, X.Y.; Chen, S.Y.; Shao, L.W.; Sun, H.Y. Changes in water use efficiency and water footprint in grain production over the past 35 years: A case study in the North China Plain. J. Clean. Prod. 2016, 116, 71-79. [CrossRef]

54. Liu, X.J.; Zhang, Y.; Han, W.X.; Tang, A.H.; Shen, J.L.; Cui, Z.L.; Vitousek, P.; Erisman, J.W.; Goulding, K.; Christie, P.; et al. Enhanced nitrogen deposition over China. Nature 2013, 494, 459-462. [CrossRef] 
55. Lu, J.; Hu, T.; Geng, C.; Cui, X.; Fan, J.; Zhang, F. Response of yield, yield components and water-nitrogen use efficiency of winter wheat to different drip fertigation regimes in Northwest China. Agri. Water Manag. 2021, 255, 107034. [CrossRef]

56. Feng, H.; Sun, F.; Liu, Y.; Zeng, P.; Che, Y. Mapping multiple water pollutants across china using the grey water footprint. Sci. Total Environ. 2021, 785, 147255. [CrossRef]

57. Lu, J.; Hu, T.; Zhang, B.; Wang, L.; Yang, S.H.; Fan, J.L.; Yan, S.C.; Zhang, F. Nitrogen fertilizer management effects on soil nitrate leaching, grain yield and economic benefit of summer maize in Northwest China. Agri. Water Manag. 2021, 247, 106739. [CrossRef]

58. Li, X.X.; Hu, C.S.; Delgado, J.A.; Zhang, Y.M.; Ouyang, Z.Y. Increased nitrogen use efficiencies as a key mitigation alternative to reduce nitrate leaching in North China Plain. Agric. Water Manag. 2007, 89, 137-147. [CrossRef]

59. Wang, S.Q.; Wei, S.C.; Liang, H.Y.; Zheng, W.B.; Li, X.X.; Hu, C.S.; Currell, M.J.; Zhou, F.; Min, L.L. Nitrogen stock and leaching rates in a thick vadose zone below areas of long-term nitrogen fertilizer application in the North China Plain: A future groundwater quality threat. J. Hydrol. 2019, 576, 28-40. [CrossRef]

60. Lu, Y.; Wang, E.L.; Zhao, Z.; Liu, X.W.; Tian, A.L.; Zhang, X.Y. Optimizing irrigation to reduce N leaching and maintain high crop productivity through the manipulation of soil water storage under summer monsoon climate. Field Crops Res. 2021, 265, 108110. [CrossRef]

61. Li, Y.; Liu, H.J.; Huang, G.H. The effect of nitrogen rates on yields and nitrogen use efficiencies during four years of wheat-maize rotation cropping seasons. Agron. J. 2016, 108, 2076-2088. [CrossRef]

62. Li, Y.; Liu, H.J.; Huang, G.H.; Zhang, R.H.; Yang, H.Y. Nitrate nitrogen accumulation and leaching pattern at a winter wheat: Summer maize cropping field in the North China Plain. Environ. Earth. Sci. 2016, 75, 118. [CrossRef]

63. Chen, C.; Wang, E.L.; Yu, Q.A. Modelling the effects of climate variability and water management on crop water productivity and water balance in the North China Plain. Agric. Water Manag. 2010, 97, 1175-1184. [CrossRef]

64. Ma, Y.; Feng, S.Y.; Song, X.F. A root zone model for estimating soil water balance and crop yield responses to deficit irrigation in the North China Plain. Agric. Water Manag. 2013, 127, 13-24. [CrossRef]

65. Pei, H.W.; Shen, Y.J.; Liu, C.M. Nitrogen and water cycling of typical cropland in the North China Plain. Chin. J. Appl. Ecol. 2015, 26, 283-296. [CrossRef]

66. Gu, L.M.; Liu, T.N.; Wang, J.F.; Liu, P.; Dong, S.T.; Zhao, B.Q.; So, H.B.; Zhang, J.W.; Zhao, B. Lysimeter study of nitrogen losses and nitrogen use efficiency of Northern Chinese wheat. Field Crops Res. 2016, 188, 82-95. [CrossRef]

67. Sun, H.Y.; Zhang, X.Y.; Wang, E.L.; Chen, S.Y.; Shao, L.W. Quantifying the impact of irrigation on groundwater reserve and crop production-A case study in the North China Plain. Eur. J. Agron. 2015, 70, 48-56. [CrossRef]

68. Wu, Y.C.; Zhou, S.L.; Wang, Z.M.; Feng, H.Y.; Lu, L.Q.; Wang, R.Z. Recovery of residual fertilizer-nitrogen by wheat in a winter wheat-summer maize rotation in the North China Plain: A soil column study. Agron. J. 2009, 101, 925-932. [CrossRef]

69. Kadiyala, M.D.M.; Jones, J.W.; Mylavarapu, R.S.; Li, Y.C.; Reddy, M.D. Identifying irrigation and nitrogen best management practices for aerobic rice-maize cropping system for semi-arid tropics using CERES-rice and maize models. Agric. Water Manag. 2015, 149, 23-32. [CrossRef]

70. Liu, L.; Yao, S.; Zhang, H.; Muhammed, A.; Xu, J.; Li, R.; Zhang, D.; Zhang, S.; Yang, X. Soil nitrate nitrogen buffer capacity and environmentally safe nitrogen rate for winter wheat-summer maize cropping in Northern China. Agric. Water Manag. 2019, 213, 445-453. [CrossRef]

71. Peng, Y.; Yu, P.; Li, X.; Li, C. Determination of the critical soil mineral nitrogen concentration for maximizing maize grain yield. Plant Soil 2013, 372, 41-51. [CrossRef] 